\title{
The mediating role of 5-HTTLPR in the background of stress vulnerability
}

\author{
Xenia Gonda \\ From $1^{\text {st }}$ International Congress on Neurobiology and Clinical Psychopharmacology and European \\ Psychiatric Association Conference on Treatment Guidance \\ Thessaloniki, Greece. 19-22 November 2009
}

The serotonergic system has been found to play a crucial role in the development of affective disorders, and more recently a functional polymorphism in the serotonin transporter gene, the 5-HTTLPR has been found to be associated with different manifestations of depressive illness. Stress has also been implicated in the background of these disorders. Research increasingly implicates that the s allele of the 5-HTTLPR leads to an increased vulnerability towards the development of depression, and this vulnerability can be manifested in several different forms. It seems from the evidence accumulating so far that the common pathway through which the s allele of the 5-HTTLPR mediates the development of affective sympotmatology is influencing vulnerability towards stress and stressful life events. Our research has shown that the presence of the $s$ allele leads to the emergence of such psychological traits which are associated with increased neuroticism and lead to less efficient coping mechanisms and less adaptive reaction in the face of adverse life events. Neuroimaging data also supports that the s allele plays a role in influencing the reaction to stressful environmental stimuli, and animal data also indicate that the 5-HTTLPR genotype interacts with adverse environmental events in influencing the emergence of behavioural and neurochemical markers of stress reaction and affective disorders. Taken together this mounting evidence increasingly points to the conclusion that the

Department of Clinical and Theoretical Mental Health and Department of Pharmacology and Pharmacotherapy, Faculty of Medicine, Semmelweis University, Budapest, Hungary
5-HTTLPR polymorphism plays a profound role in mediating the effects of stress and stressful life events.

Published: 22 April 2010

doi:10.1186/1744-859X-9-S1-S38

Cite this article as: Gonda: The mediating role of 5-HTTLPR in the background of stress vulnerability. Annals of General Psychiatry 2010 9(Suppl 1):S38.
Submit your next manuscript to BioMed Central and take full advantage of:

- Convenient online submission

- Thorough peer review

- No space constraints or color figure charges

- Immediate publication on acceptance

- Inclusion in PubMed, CAS, Scopus and Google Scholar

- Research which is freely available for redistribution

Submit your manuscript at www.biomedcentral.com/submit
C Biomed Central 